\title{
オオチョウバエの生活史の観察と幼虫に対する 殺虫剂感受性テスト1)
}

\section{Notes on bionomics of the moth fly (Telmatoscopus albipunctatus}

Williston) and insecticide susceptibility test to the larva1)

\author{
森谷清樹2）矢部辰男2）原田文雄2) \\ Kiyoki Moriya, Tatsuo Yabe and Fumio Harada ${ }^{2}$
}

1967年頃より，每年夏から秋にかけ，神奈川県下の各 地でチョウバエ類が多発生し，いわゆる“ニューサン ス”として，しばしば問題になつた。このチョウバェ類 は, ホシチョウバエ Psychoda alternata Say と才オチ ヨウバェ Telmatoscopus albipunctatus Williston の 2 種が主なもので，人体内迷入例（ホシチョウバエによ るもの：徳永, 1943 ; Tokunaga, 1953 ; 上村, 1967 ; およびオオチョウバエによるもの：森下，1950；Tokunaga，1953）もわが国で知られている. ホシチョウバ 工注，下水処理施設に大発生することがあり，下水ば え, 万床ばえ, Sprinkler sewage filter fly と呼ばれ, 多数の生活更観然，駆除头験の報告 (Headlee and Beckwith (1918), Headlee (1919), Brothers (1946), Carollo (1946)，Warrick(1946)など) があり，わが国でも，石 井・原由（1960）が駆除の試名打こなつている。しか しながら，才オチョウバエについては，わが国での生活 史, 生態扰よび殺虫剂に対する感受性についての報告は 見あたらない。

このような事情から，本種駆除の基礎資料女得る目的 で，野外でオオチョウバェを採集し，垁験宝内で生活史 の観察と防疫用殺虫剂による幼虫の感受性テストをおこ なつた。

\section{オオチョウバェの形態と被害の概況}

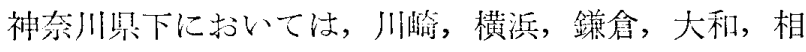
模原の各地で，1967，1968年の特に夏から秋にかけ被害 が見られた。被贯は，多発生時に家屋入侵入し居住者に 不快感を与えるもので，人体青生，刺咬などの直接的被

1）本研究の一部は籍 21 回山本衛生得物学全大全 (1969，長崎）にて報告した。

2) 神然川県衛生研究所

Kanagawa Prefectural Public Health Laboratory, Yokohama
覧はない。しかし，本種の発生場所から考え，食物など を污染する可能性が認められる，一般に便所（水洗）,

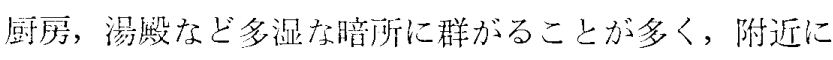
発生源が見出される。発生源は，主として家庭污水の浄 化榑，不完全排水溝ならびに家竞全の排水榑など有機物 の多い水域である。

オオチョウバェ*の形態については，徳氷(1951, 1959）が幼虫之蛹について，Tokunaga (1953，1955）

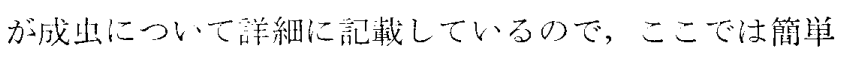
に記しておく。

成虫：チョウバエとしては大型，体長む〜 $5 \mathrm{~mm} に$ 達し，褐色を㧍びた黑灰色で全体表に長い剛区が必生し ている。頭部は小さく，背上面から沟部と阔毦にかく れ見えない。闭複眼注近接し，単眼はない。触街は16節 からなり，各節は同型で站部の長いフラスコ型をして打 り, 各節とも多数の感筧毛があり一対の感筧晒管（as-

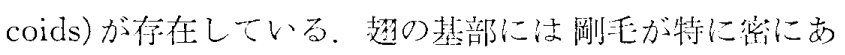
り, 翅の企体は黑褐色であるが, $\mathrm{R}_{1}, \mathrm{R}_{2}, \mathrm{R}_{3}, \mathrm{R}_{4}, \mathrm{MM}_{2}$, $\mathrm{M}_{3+4}, \mathrm{Cu}_{1}$ の末端部に白毛が皮しして白点をつくり， $\mathrm{R}_{2+3}$ の分肢点， $\mathrm{M}_{2}$ の基部ならびに $\mathrm{Cu}$ の顶点に黑毛密 生による黑点がある。雄の尾節にはボーリングのピン状 腹把握器があり, その先端部に多数の小棘が存在する, 雌の两生殖板は幅広く，表面は微毛に枋扮われ，ところ どころに長毛がある。

幼出：成熟したもので体莀 $8 \sim 9 \mathrm{~mm}$ に達し, 頭幅は $0.4 \sim 0.5 \mathrm{~mm}$ で, 企体は褐色に芫え, 斯部, 尾端は黑 褐色である。背面に注黑褐色の背硬板が発達し，小刺毛

*才オチョウバエの和名について，徳永(1951)はケチ ヨウバエ，徳永(1959)はオオケチョウバェし記して いるが，德永(1965) でオオチョウバエ上なつてい る. いずれも同一種 Telmatoscopus albipunctatus についての和名でありここではオオチョウバエに 統一した. 

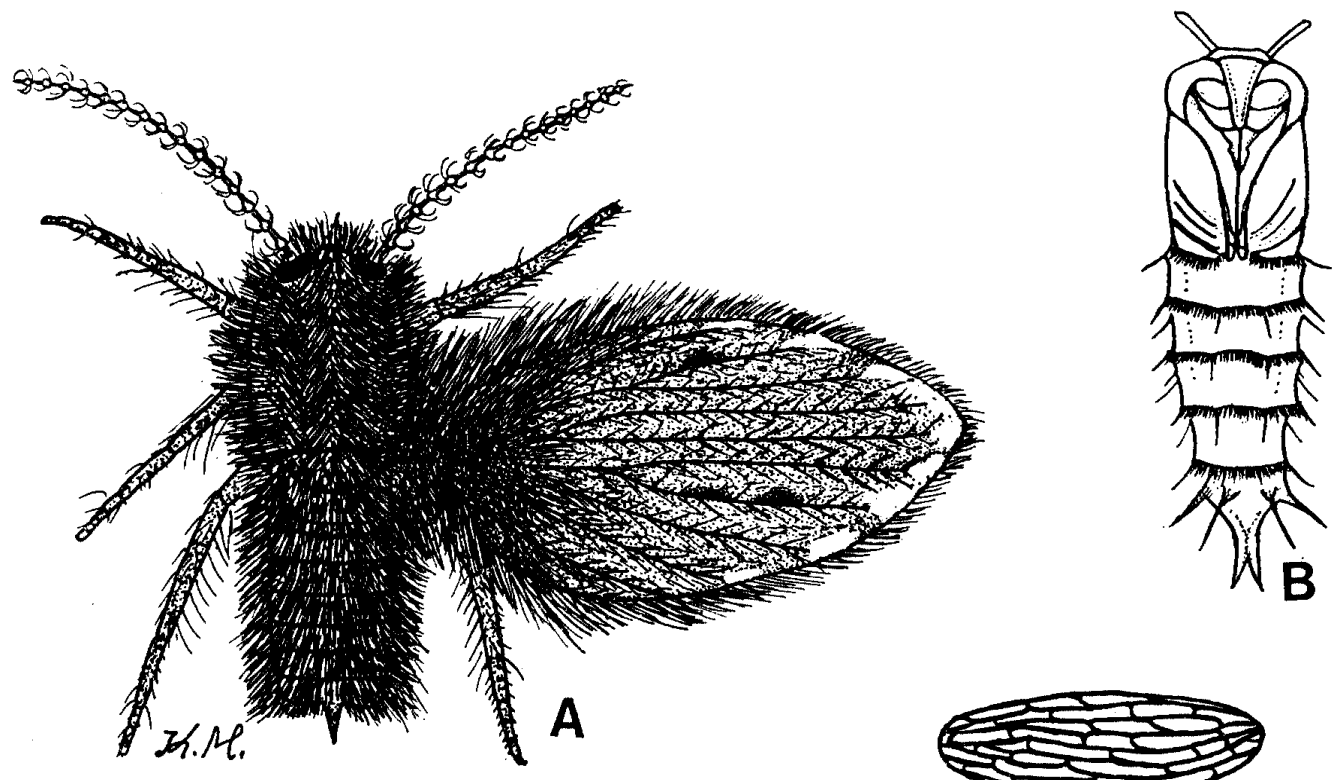

Fig. 1. Life stages of Telmatoscopus albipunctatus A, Adult (우); B, Pupa ; C, Larva ; D, Egg
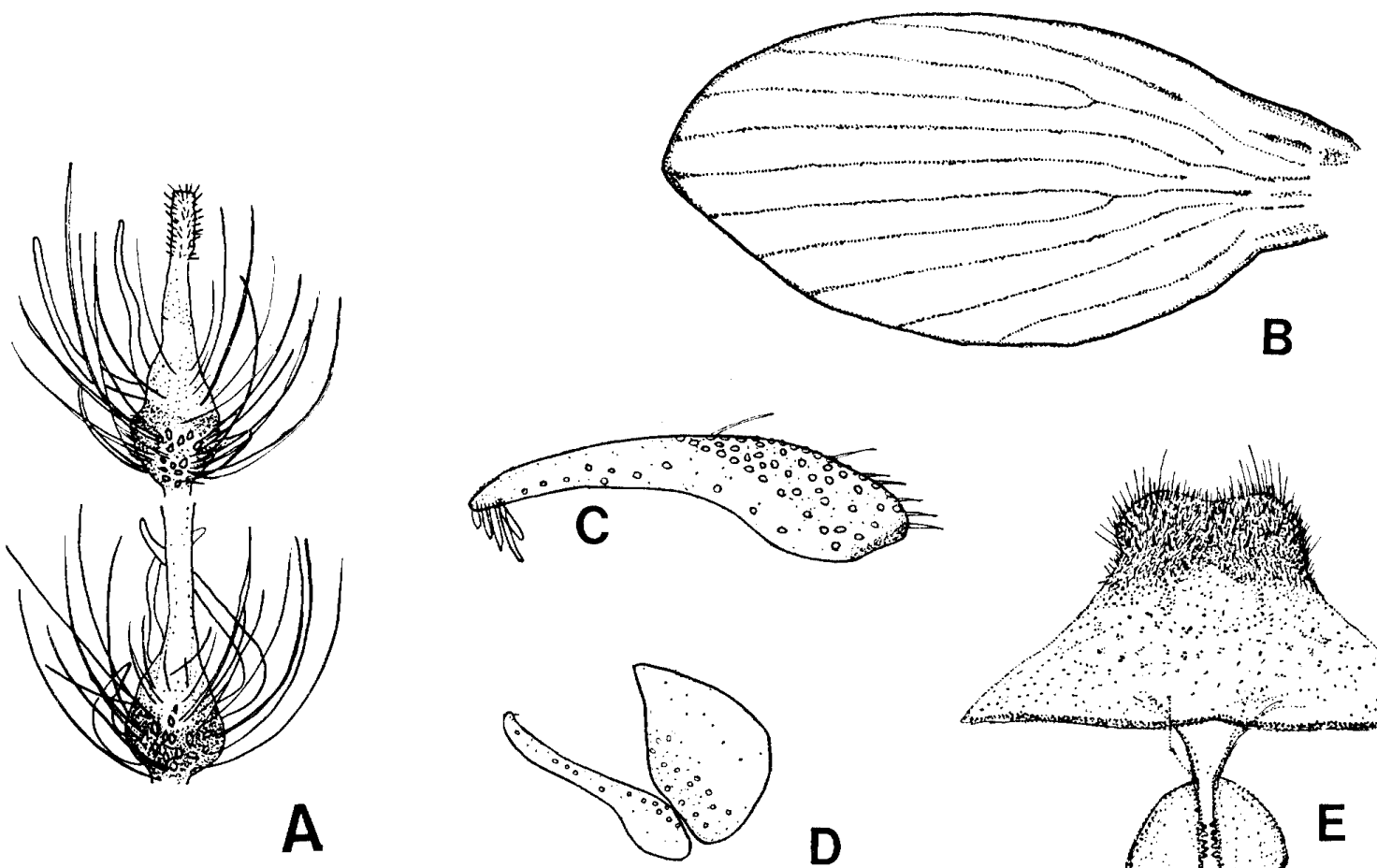

D

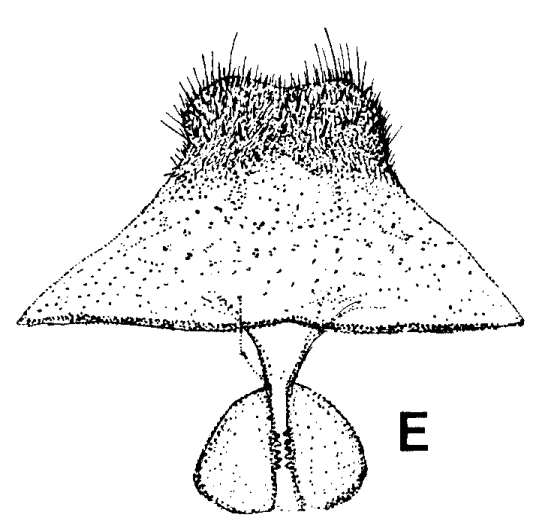

Fig. 2. A, distal end of female antenna; B, Female wing; C, Cercus of male hypopygium; D, Coxite and style of male hypopygium; $\mathrm{E}$, female subgenital lob with spermathecae.

と多数の剛毛がある，背硬板は，胸部と第 1 腹部の各節 にはそれぞれ $2 つ ，$ 第 2 腹節より第 7 腹節にはそれぞれ 3 つ存在している. 呼吸管は黒褐色で円錐型である.

蛹: 全長 $5 \sim 6 \mathrm{~mm}$, 暗褐色で剛毛が分布し，特に腹 部環節後縁に密汇列生している. 背面には帯状の隆起が
あつて，腹板と同様に剛毛が列生し，特に中央部および 側面部の後縁には細毛がくし状に配列され，尾端には強 大な㴊毛と 1 対の角状突起を具える.

卵：白ないし淡褐色で長径 $0.45 \sim 0.48 \mathrm{~mm}$, 短径 0.12 $\sim 0.15 \mathrm{~mm}$ の大きさ，表面に特有な網目状紋が見られ 


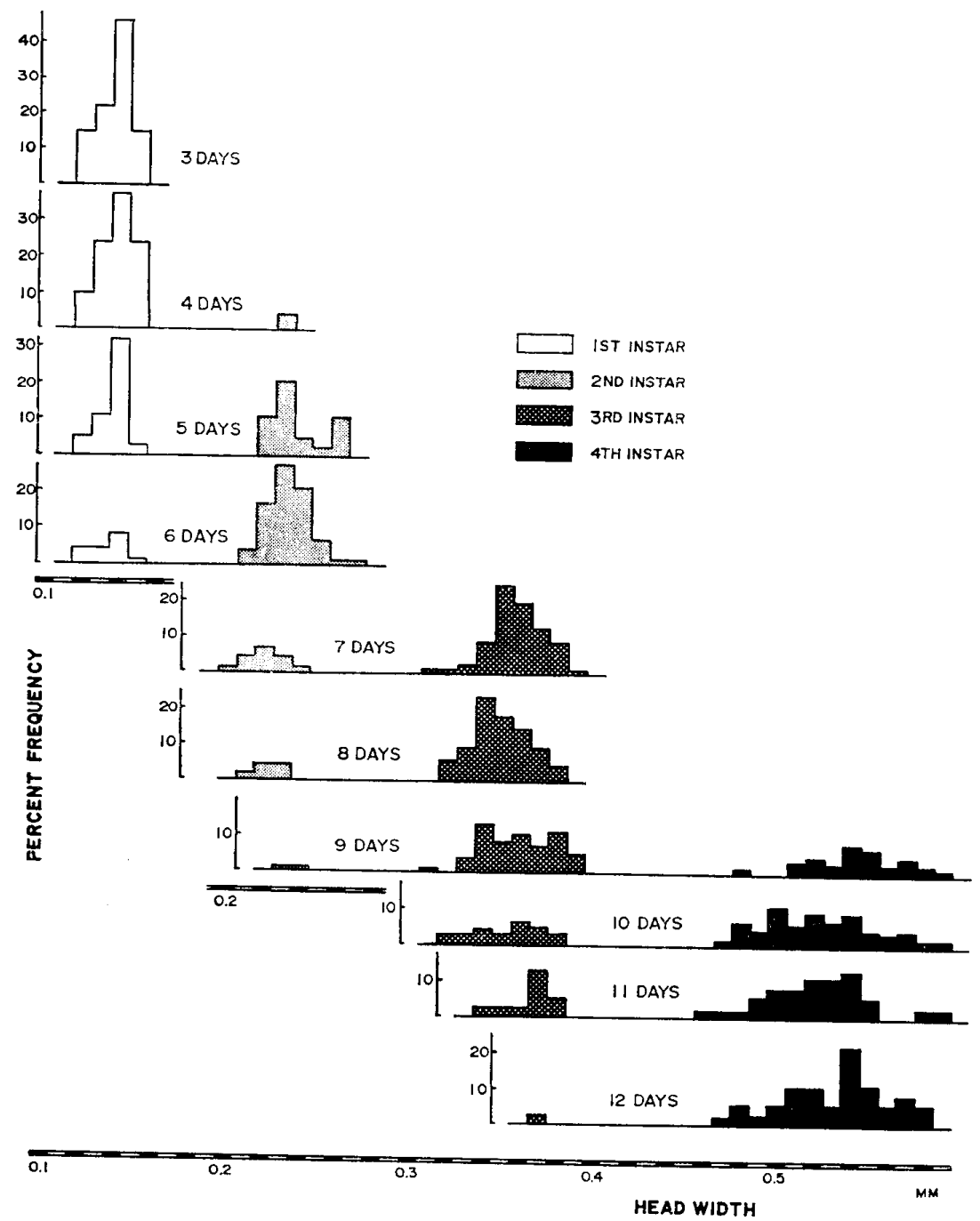

Fig. 3. Percent distributions of head width Telmatoscopus albipunctatus larvae at each successive day after rearing.

る.

本種は、 ヨーロッパ，アフリカ地中海㳂呩，フィリッ ピン, 八ワイ, 北アメリカ太平洋沿琵に広く分布し, 国 内では沖綎，福阙，大阪，京都など西南部に分布が知ら れている。

Tokunaga $(1953 ， 1955)$ によれば，本種は熱带地方に 広く分布し，近年日本に到着したものと考えられている。 われわれて神奈川県下に朽ける調查によれば，1962年の 夏季に大䂺町の出る浄化そう内に初为て見出された。 の後1967年以後に汶舅下各地に見られるよらになつた。 すなわち1967年11月に調查した大和市の5 基の浄化こう 全部に，1968年10月に調查した相模原市の21基の浄化そ ら中18进に才才チョウバエの発尘が認的ら机ている。 1969年になつて，さらに見出される場所は多くなり（秦 野市, 松田町), ま充同一浄化乞うからホシチョウバエ, オオチョウバエの雨種が（発生部位は異る）採集され た。また，し尿処理施設の散水万床（藤沢市）にも本種
の大発生が見られている。このように，オオチョウバエ はしだいに分布圈を抎げて抢り，南方系㩆虫の北淮現象 の著しい1例であると思われる。

\section{飼育と観察}

野外で採集したオオチョウバエ成虫を， $30 \mathrm{~cm}$ 角の飼 肯かごに収容し，飼料および産卵床として，直径 $9 \mathrm{~cm}$ のペトリー业に淔径 $15 \mathrm{~cm}$ の滤紙を円錐形に折り曲げて 入れ, 乾燥醉母「エビオス」の10倍液（重量比） $20 \mathrm{ml}$ をその上からかけて上えた。産卵が認められたら，卵を 滤紙ごと飼育バット（深さ $10 \mathrm{~cm}$, 横 $20 \mathrm{~cm}$, 幅 $30 \mathrm{~cm}$ ) 人 移し，水深 0.5 1 cm になるように汲み置き水道水を 加光，水面に被膜が生ずるのを防ぐためェアレーション を抗こなつた，飼育開始日から蛹化が始まるまで往日工 ビオス $0.5 \sim 1 \mathrm{~g}$ を加え, 水は幼虫の成㙊にともなつて

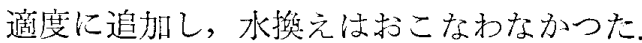

本種の幼虫注尾端を水面上にあげ呼吸しながら底面を 


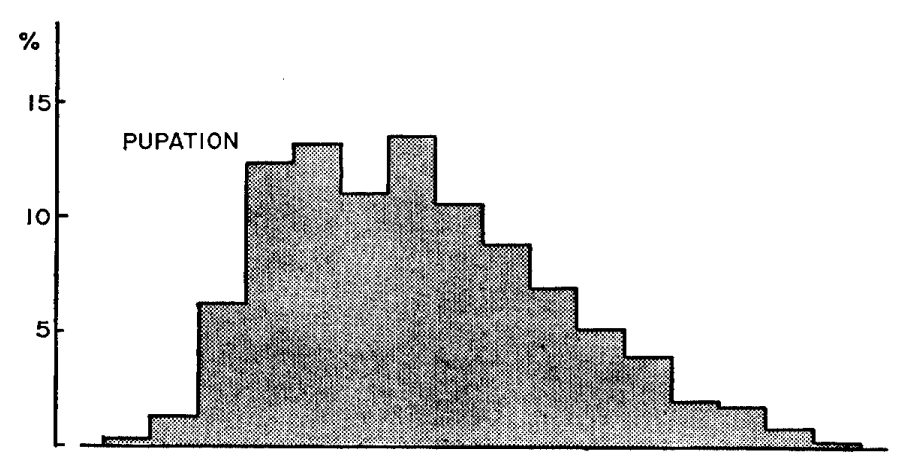

$\%$

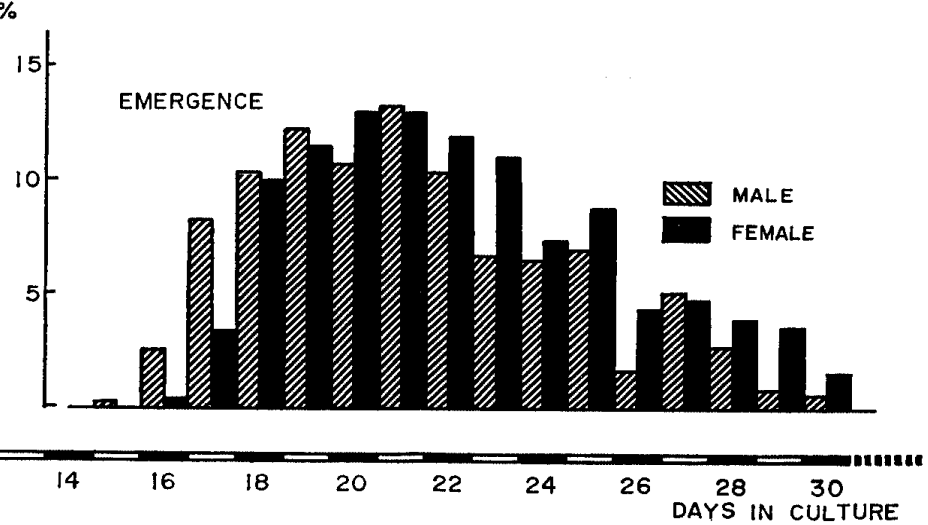

Fig. 4. Daily occurrences of pupae and adults of colonized Telmatoscopus albipunctatus in percentage.

歩き拱食するのが観察され，水深が深くなると蚊幼虫の ように浮上せず, やがて死亡する。これを防ぐため，飼 育バットを傾け，氷深に公配を作り，また素焼板を水中 に入れた。

蛹化個体は飼育バットより飼育かごに移し羽化させ た. 水深を深くすると, 幼虫は沈むが, 羽化が近くなつ た蛹は浮上するので両者の分離は容易である. 飼育は 1 飼育バットあたり 1000 2000個体を， $27^{\circ} \mathrm{C}, 85 \% \mathrm{RH}$ に保たれている恒温室内で $12 \mathrm{~L}: 12 \mathrm{D}$ 光条件（人工照 明，最高時 360Lux）下でおこなつた。

\section{オオチョウバェの生活史}

オオチョウバエの卵は水面まぎわの濾紙上に附着し て, 不規則な塊状に産出される. 1 雌の産卯数, 産卵回 数は不明であるが，20個体の未産卵雌の剖検によれば, 抱卵数120 328 (平均 241土16.6) であつた. 卵巣の発 達状態からみて，数回に生み分けられるものと推定され る. 卵期間 2 日で，卵の先端から中央に向い約 $1 / 4$ ぐら いまで卵膜が破れ，ふ化がおこなわれる。

ふ化後, 毎日一定時刻に飼育中のオオチョウバエ幼虫 50 100 個体を無作為にとり, ウルマー氏液で 固定し, 最大頭幅を実体顕微鏡下でマイクロメーターにより測定 した. 計測值の分布を百分率で示したのが図 3 である.
表 1 各令期の頭幅上体舆

Table 1. Head width and body length in millimeters of the instars

\begin{tabular}{r|cccc}
\hline instar & \multicolumn{2}{|c}{ head width } & \multicolumn{2}{c}{ body length } \\
mean & range & mean & range \\
\hline I & 0.14 & $0.12-0.15$ & 1.05 & $1.0-1.1$ \\
II & 0.23 & $0.22-0.27$ & 2.5 & $2.3-2.7$ \\
III & 0.35 & $0.31-0.45$ & 4.3 & $3.5-6.1$ \\
IV & 0.52 & $0.48-0.59$ & 9.5 & $9.4-9.6$
\end{tabular}

表 2 供試した殺虫剂

Table 2. List of insecticides tested

\begin{tabular}{ll}
\multicolumn{1}{c}{ Insecticide } & Purity in Percent \\
\hline 1. DDT (pp'-DDT) & $98 \%$ technical material \\
2. Lindane ( $\gamma$-BHC) & $99 \%$ technical material \\
3. Baytex (fenthihn) & $97.2 \%$ technical material \\
4. Diazinon & $94.7 \%$ technical material \\
5. Sumithion (fenitro & $98.7 \%$ technical material \\
thion) & $97 \%$ technical material \\
6. DDVP (dichlorvos) & $40 \%$ ethanol sol. \\
7. Dipterex (trichlorfon) & $97 \%$ technical material \\
8. Malathion & $95 \%$ technical material \\
9. Sevin &
\end{tabular}


表 3 オオチョウバエ幼虫に対する各種殺虫剤の効果(处理24時閒後の死亡百分率)

Table 3. Results of insecticidal susceptibility tests with Telmatoscopus albipunctatus larvae (Percentage mortality of after 24 hours exposure)

\begin{tabular}{|c|c|c|c|c|c|c|c|c|c|c|c|c|c|c|c|}
\hline \multirow{2}{*}{ Insecticide } & \multicolumn{15}{|c|}{ concentration in ppm } \\
\hline & 0.01 & 0.05 & 0.1 & 0.2 & 0.25 & 0.5 & 1 & 2 & 2.5 & 5 & 10 & 20 & 40 & 100 & 200 \\
\hline Baytex & 0 & - & 30 & - & 40 & 80 & - & 100 & i & & & & & & \\
\hline Sumithion & & 0 & - & 20 & - & 25 & 60 & - & 85 & 100 & & & & & \\
\hline Diazinon & & & & - & 0 & 5 & 20 & - & 60 & 95 & 100 & & & & \\
\hline Dipterex & & & & 0 & - & - & 10 & - & 40 & 60 & 100 & & & & \\
\hline Malathion & & & & & & 0 & 10 & - & 35 & 55 & 80 & 100 & & & \\
\hline Lindane & & & & () & - & - & 10 & 15 & - & 30 & 60 & 100 & & & \\
\hline DDVP & & & & 0 & - & - & 7.5 & - & 10 & 40 & 65 & 100 & & & \\
\hline DDT & & & & & & 0 & 10 & 15 & - & 45 & - & 60 & 90 & 100 & \\
\hline Sevin & & & & & & & & 0 & - & - & 10 & 45 & 40 & 70 & 100 \\
\hline
\end{tabular}

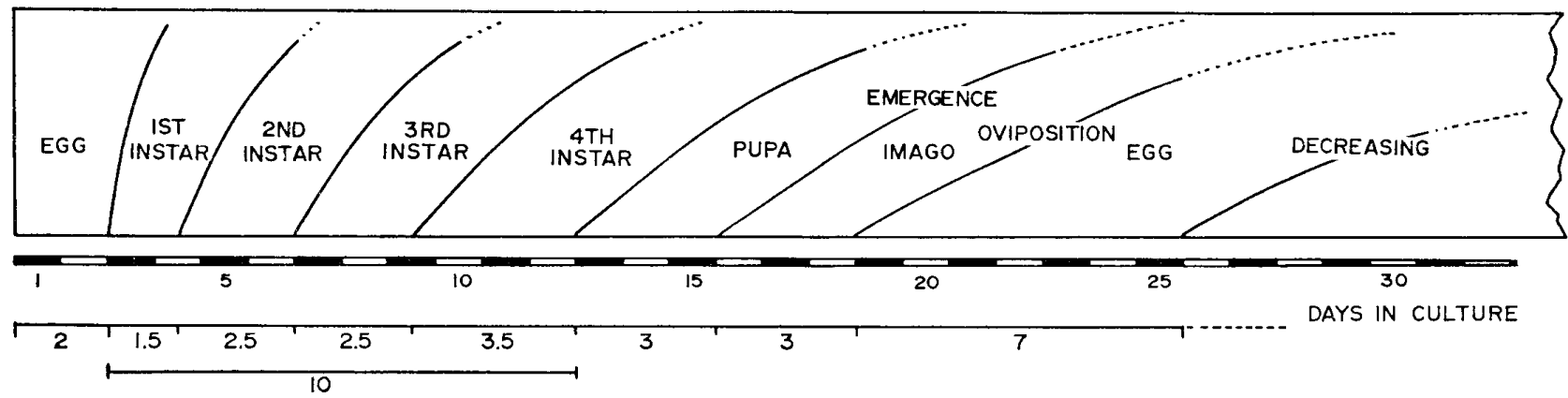

Fig. 5. Diagram shows development of Telmatoscopus albipunctus reared under the laboratory condition.

図 3 から判断できるように，才オチョウバエ幼虫は 4 期 を経過し，それぞれ各期の体長および頭幅の平均值は表 1 に示したとおりである。呼吸管長の測定倠は各令期で 重複することがあり，命期の判定には用いられないので 省略した。

蛹化は，飼青開始後12日目から始まり，しだいに增加 し，16日，17日目に最高となり，その後は減少する。蛹 化状況についての観察は，飼育開始後28日目で中止した が，蛹化までの所要日数にはかなり大きな個体差のある ことを認めた。羽化は15日目からはじまり，雄では20日 目に羽化寸る個体が一番多かつた。同一日に産卵された ものについて，個別に飼资し約 300個体について羽化時 の性比を調べた結果，雌 100に対し雄 124でやや雄が多 かつた，交尾注いつ始まるのか不明であるが，金網上に 静止している羽化 2 日目の雌に雄が近ゔくのがしばしば 観察された。

雌の産卵は羽化 3 日，4 日目から開始される。この飼 育条件下での成虫の寿命は比較的短く, 羽化後 3 日， 4 日後より死亡する個体があり，その数はしだいに増加し
羽化後 2 週問以内にはほとんどが死亡するるが，一部のも のは，1力月以上も生存した。調查した生活串在模式的 に図示したすのが図 5 である。

\section{殺虫剂感受性試験}

供試薬剤：塩素系の DDT. リンデンの2 種, 有機燐 系のフェンチオン，フェニトロチオン，ダイアジノン，デ イプテレックス，マラソン， DDVP の6稞にカーバメ イト系のセビンを加えた 9 種類についてテスト在好こな つた、いづれも原体を所定のエタノール溢泣として用い た。使用した原体の純度は表 2 に示す通りであるが，こ こではすべて純度 100\%と仮定して取扱つた。

供試虫：生活史の観察に用いた飼育方法と同一方法で 飼育し，4令幼虫をテストに用いた.

テスト方法：種々の予備試験の結果からつぎの強制滤 紙接触法と液浸法の併用法というべき方法を用いた。す なわち, 直径 $9 \mathrm{~cm}$. 高さ $8 \mathrm{~cm}$ の腰高シャーレに脱イオ ン水を $50 \mathrm{ml}$ 入れ. これに直径 $15 \mathrm{~cm}$ の濾紙を円錐形に 折つて入れ，殺虫剤エタノール液を $1 \mathrm{ml}$ 入れた場合に 


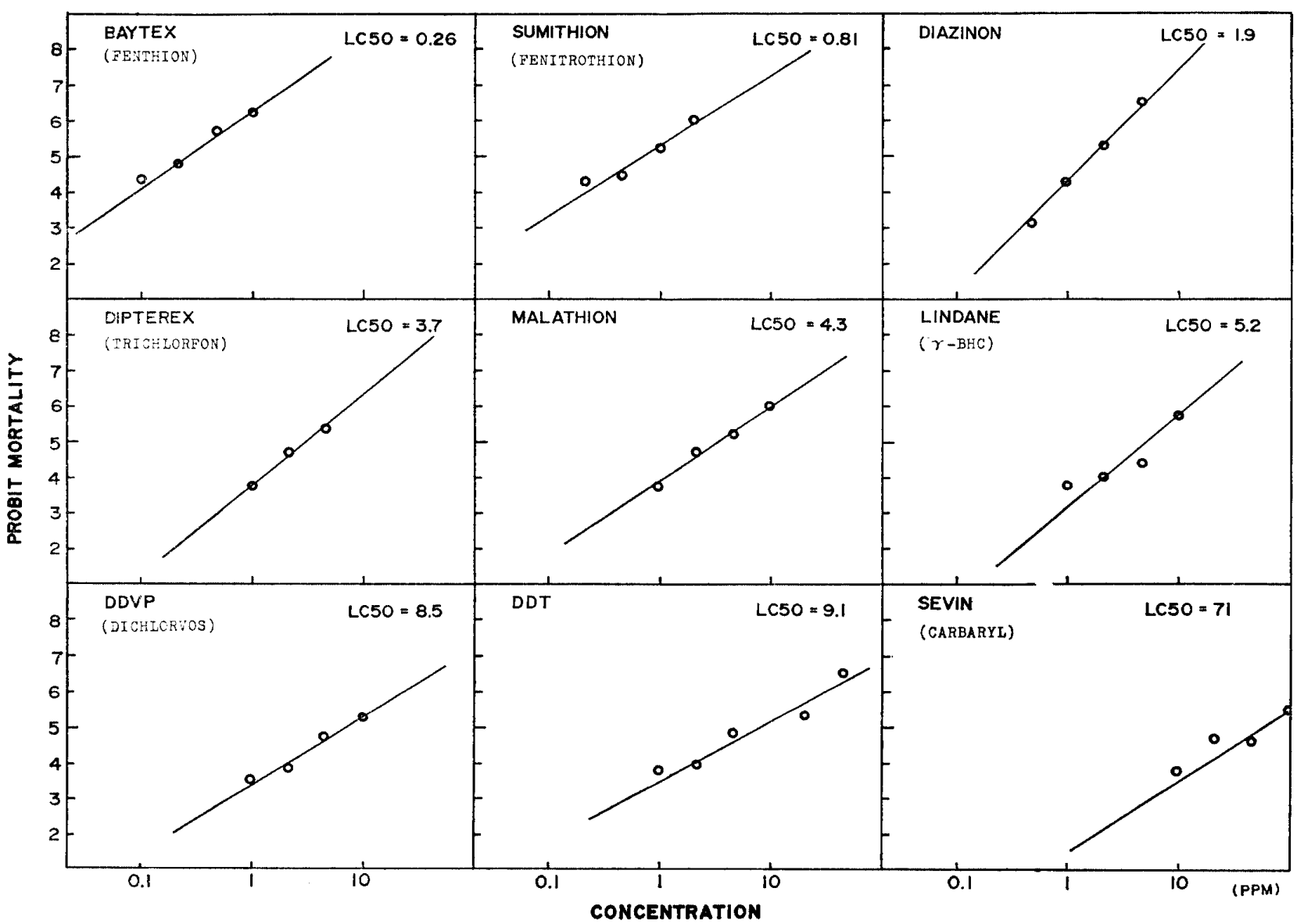

Fig. 6. Log. dosage-probit lines and LC 50 values of various insecticides to larvae of Telmatoscopus albipunctatus by the dilution immersion method with suspending filter papers.

所定の源度になるよう試験区を設定した。1 殺虫剤に対 し，おのおの 5 倍希勫， 5 段階を 1 シリーズとしてテス 卜をおこなつた。

この方法によると，円錐形に折られた濾紙の上部は試 験液を含んでいるが，液面より露出し，実験中しばしば 供試幼虫がこの部分をはうのが観察され，この部分では 強制濾紙接触法と同様な影響を与えているものと観察さ れる。この方法では当然ながら単なる液浸法によるテス トに比較して殺虫剤感受性は低く評価されるが，オオチ ヨウバエの自然生息場所にお打る行動から見て, 上り実 際的な殺虫剂感受性の評価が得られるものと考えられ る。テストは同一薬剤に対し 3 回以上くり返し， $27^{\circ} \mathrm{C}$ の条件でうこなわれた。

供試虫数は 1 区につき10個体，24時間後の死亡数を求 め, 中毒個体注死亡虫に含めた.

テスト成績: 表 3 は, 各濃度にお拈けるオオチョウバエ 幼虫の死亡率を示したものである.この表から見ると， 最も効果が高いのはバイテックスであり，ついでスミチ オン, ダイアジノン, ディプテレックスの效果が高く, つぎにマラサイオン, リンデン, DDVP と続き, DDT,
セビンの効果は低い.

各薬剂ごとに, 各濃度に㧍ける死亡率をプロビット変 換し, Finney の図解法によつて 濃度死亡率プロビット 回帰直線を求め， $\mathrm{LC}_{50}$ 值を算出した（図 6 )。得られた $\mathrm{LC}_{50}$ 值は, 薬剂により，かなりの差異が認められる が，いゔれの薬剤に対してもかなり感受性が低い，これ らの LC 50 值は，八エ幼虫（イエバエ，センチニクバ エ）に匹敵し，オオチョウバエ幼虫の大きさを考えるな らば，殺虫剂に対して，いちじるしく強いように思われ る.

発生源対策として，殺虫剂による本種の駆除を行な う場合には，殺虫力の高かつたバイテックス，スミチオ ン, ダイアジノンが有力候補となるであろうが，かなり の高濃度 $(5 \sim 10 \mathrm{ppm})$ 撒布する必要があり, 薬害に注 意する必要が生じる。したがつて実際の駆除対策として は，幼虫よりも成虫駆除対策を考えるほうが得策ではな いかと思われる。 


\section{まとめ}

神奈川䀃下で，夏から秋にかけオオチョウバェ Telmatoscopus albipunctatus が浄化そうや不完全排水溝 などから多発生し，しばしば家屋内に侵入して，いわゆ る“ニューサンス”として問題となつた，そこで本種を 室内で飼青し，生活史の観察と9 種の殺虫剤について幼 虫の感受性テストを抗こなつた、結果のあらましはつぎ のようであつた。

1) 温度 $27^{\circ} \mathrm{C}$ ，湿度 $85 \% \mathrm{RH}, \mathrm{L} 12: \mathrm{D} 12$ の光条件 で，エビオスを飼料として飼育した結果では，不規則な 塊状に水際に産卵され，卵期間 2 日，幼虫期間約10日で 4 令学経過し, 蛹期は $3 \sim 4$ 日で, 雄が雌よりも約 1 日 早く羽化する。羽化後 4 日目頃より産卵がはじまる。こ の条件下では成虫の寿命は比較的短く, 羽化後 $10 \sim 15$ 日 間に大部分のものが死亡した。

2）殺虫剤エタノール溶液 $1 \mathrm{ml}$ を $50 \mathrm{ml}$ の脱イオン 水に入れ所定の濃度区を作り，各試験区には濾紙を入 れ, 液浸法と強制濾紙接触法の併用法により殺虫剂感受 性を調べた。

算出された $\mathrm{LC}_{30}$ 值は,順にバイテックス $(0.26 \mathrm{ppm})$ ， スミチオン $(0.81)$ ，ダイアジノン (1.9), ディプテレッ クス (3.7), マラソン (4.3), リンデン (5.2), DDVP (8.5), $\operatorname{DDT}(9.1)$, セビン (71) であつた.

結果から見ると本種幼虫の殺虫剂感受性は低く, した がつて殺虫剂による本種の駆除は, 成虫を目標にして実 施するのが得策であると思われる。

\section{文献}

1) Brothers, W. C. (1946): Experiments with DDT in filter fly control. Sewage Works Jour., $18: 181$. -2) Carollo, J. A. (1946): Control of trickling filer flies (Psychodidae) with DDT. Sewage work Jour., 18 : 208-211. -3) Headlee, T. J. \& Beckwith, C. H. (1918): Sprinkling filter fly, Psychoda alternata Say, J. econ. Ent., 11 : 395-401. -4) Headlee, T. J. (1919): Practical application of the method recently discovered for the control of the sprinkling sewage filter fly, Psychoda alternata Say, J. econ. Ent., 12 : 35-

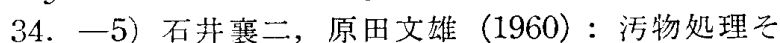

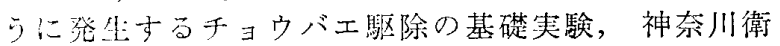
硎淑，10:51-55. 一6) 上村清(1967)：ホシチョ
ウバエ幼虫の眼寄生と思われる1症例について，衛 生動物, 18(4) : 305-306. -7) Livingston, A. M. (1951) : Trinckling filter fly conrol. Sewage and Industrial Wastes, 23 : 241-244. -8) 森下薰(1950) Tokunaga (1953) より引用. - -9) 徳永雅明 (1943)： 医用昆虫学, 上巻, 851頁, 診㙩と経験社, 大阪。一 10) 德永雅明 (1951)：日本幼虫図鑑学生版，315頁， 北隆館, 東京. - 11) Tokunage, M. (1953) : Moth-flies that cause myasis in man in Japan. J. Sanit. Zool. 4 : 101-107. -12) Tokunaga, M. \& E. Komyo (1955): Japanese psychodidae III. New or little-known moth flies with new descriptions of ten new species. Phillippine Jour. of Science, $84: 213-215$. - - 13) 徳永雅明 (1959)：日本幼虫図 鑑. （623）712頁，北隆館，東京. -14）徳永雅明 （1965）原色昆虫大図鑑第 3 巻 (182) 358頁，北隆館， 東京. - 15) Warrick, L. F. \& Bernauer, G. F. (1946) : How to use DDT for insect control. Waste and Sewage Works, 93 : 329-332.

\section{Summary}

As a case of insect nuisances of summer season two kinds of the moth flies, Psychoda alternata Say and Telmatoscopus albipunctatus Williston, which are common in various districts of Kanagawa Prefecture, was in vestigated.

The life history of Telmatoscopus albipunctatus was observed in the laboratory by dry yeast feeding under the conditions of $27^{\circ} \mathrm{C}, 85 \%$ relative humidity and L $12: \mathrm{D} 12$ in photoperiodism. The egg period was 2 days, larval stages ranged 10-14 days (I, II, III and IV instar periods), pupal period was 3 days and adult life lasted from 2 days to 20 days (average 7 days). Preoviposition period was 3 days, and the total number of eggs per one female was considered to be 250 .

Relative effectiveness of 9 insecticides was tested against larvae of Telmatoscopus albipunc. tatus by the dilution immersion method with suspending filter papers. The LC 50 values were $0.26 \mathrm{ppm}$ for Baytex, $0.81 \mathrm{ppm}$ for Sumithion, $1.9 \mathrm{ppm}$ for Dipterex, $4.3 \mathrm{ppm}$ for Malathion, $5.2 \mathrm{ppm}$ for Lindane, $8.5 \mathrm{ppm}$ for DDVP, 9.1 ppm for DDT and $71 \mathrm{ppm}$ for Sevin. It was obvious that the moth fly (Telmatoscopus albipunctatus) larvae have, in general, resistance levels to the insecticides tested. It is, therefore suggested that chemical control measure of the adult moth flies, is in practice desirable. 